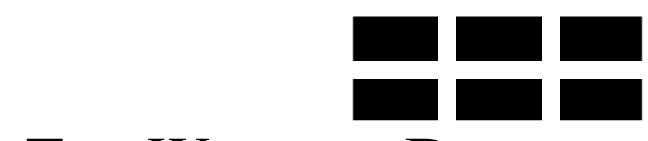

ThE WILLIAM DAVIDSON INSTITUTE AT THE UNIVERSITY OF MICHIGAN BUSINESS SCHOOL

\title{
Is Kazakhstan a Market Economy Yet? Getting warmer....
}

\author{
By: Sharon Eicher
}

William Davidson Institute Working Paper Number 673

April 2004 


\title{
Is Kazakhstan a Market Economy Yet? Getting warmer....
}

\author{
Dr. Sharon Eicher
}

eicher@kimep.kz, sharoneicher@hotmail.com

KIMEP

Department of Economics

Abai 4

Almaty 480100

Kazakhstan

2004

KEYWORDS: Market economy, non-market economy, Kazakhstan, CIS, Kornai, Svejnar 


\begin{abstract}
:
Transition from planned to a market economy is an evolutionary process. Evolutions do not have finite beginning and ending points. We may look to the beginning of transition in 1991 when the Soviet Union broke up, or we may see it as beginning earlier, when the Soviet Union began to allow its firms to engage in private sales of output that exceeded state plans and to independently take part in international trade agreements. At what point do we say that transition is complete? Hence, it is quite difficult to say when any country begins and completes its transition.

The United States and the European Union have categorized Kazakhstan differently with regard to its degree of transition. The United States removed "non market economy" status from Kazakhstan, whereas the EU gave Kazakhstan an intermediate status.

The first question that this work asks is how do these political bodies rank a country's market orientation, and how did they arrive at different conclusions?

These results are then compared to what transitional economists have to say on the evolution from a planned to a market economy. The second question is, how do theoretical, academic economists differ in their analysis of the transition process? By creating unique criteria sets from several papers, can one say that, according to any set, Kazakhstan is a market economy?

We conclude that the reform process in Kazakhstan is still underway. The government and the economy have experienced many radical reforms, but none completely satisfies the necessary conditions for being categorized as a market economy.
\end{abstract}


There are some transition economies which everyone agrees have enjoyed great success in reverting to a market economy, such as Slovenia. Other countries, such as Turkmenistan, everyone agrees is neither a market economy nor a democracy. Other countries, such as Kazakhstan, are much more difficult to gauge. This paper looks at the conclusions from the USA, the EU, and work by theoretical economists, to answer whether or not Kazakhstan has become a market economy, as the U.S. government has declared it has. The conclusion is that it is "getting warmer," but cannot be said to satisfy the criteria sets for a market economy.

Kazakhstan began its gradual reform process in 1992. In many areas, such as its pension reform, which created a pay-as-you-go system, or in the development of its banking sector, Kazakhstan appears to be a model transition economy. Kazakhstan plans to privatize all land in 2007. However, an EU document states also that "structural and fiscal reform are still very much lagging behind, while corruption continues to be widespread."

There is a difference between the criteria sets and the conclusions by the United States and by the European Union on Kazakhstan's market status. To the EU, Kazakhstan improved from non-market economy to "special status" (still not a market economy) in 2000. In 2002, Kazakhstan officially became a market economy to the American government.

Oddly enough, it is not economists, but politicians who make a decision about which country "is" and which country "is not" a market economy. ${ }^{2}$ The Department of Commerce in the United States labels economies as "market economy" or "not market economy." The European Union assigns to a country "market economy status" when it publishes lists of those countries accused of permitting dumping.

In 2001, President Bush made the recommendation to Congress that Kazakhstan be taken of the Jackson Vanik List. In March 2002, the U.S. Department of Commerce officially revoked Kazakhstan's non-market economy status. Its finding was that Kazakhstan had been effectively a market economy since October $2001 .^{3}$

In its August 2002 report on Bilateral Trade Relations, ${ }^{4}$ the EU still considered Kazakhstan to be a "non-market economy regime."

\footnotetext{
${ }^{1}$ European Union. 2001. The EU'S relations with Kazakhstan.

${ }^{2}$ When the U.S. declared Russia to be a market economy, there was much speculation in the press that this result was politically-motivated.

${ }^{3}$ Department of Commerce (Office of Public Affairs). 2002. FACT SHEET, Market Economy Analysis of Kazakhstan. <http://www.ita.doc.gov> (22 February 2003)

${ }^{4}$ European Union. 2002. Bilateral Trade Relations, Kazakhstan, August.
} 
In 1998, Kazakhstan is grouped with non-market economy countries in an EU regulation. Along with Kazakhstan were Albania, Armenia, Azerbaijan, Belarus, Georgia, Kazakhstan, North Korea, Kyrghyzstan, Moldavia, Mongolia, Tajikistan, Turkmenistan, Ukraine, Uzbekistan, and Vietnam.

Within two years, this status changed. The EU has recognized that while Kazakhstan may not yet be a "market economy," it has made significant progress:

The process of reform in the Ukraine, Vietnam and Kazakhstan has fundamentally altered the economies of those countries and has led to the emergence of firms for which market-economy conditions prevail. These three countries have as a result moved away from the economic circumstances that inspired the use of the analoguecountry method. ${ }^{5}$

Kazakhstan was granted a "special market economy status" by the EU in $2000{ }^{6}$ This is an intermediate category in between market economy and non-market economy status. Kyrghyzstan also has this special status.

These events beg two questions:

- Firstly, How is it that the USA and the EU have not come to the same conclusion regarding Kazakhstan's progress towards a market economy?

- Secondly, since it is political organizations, not economic ones, that assign "market economy" status, is Kazakhstan a market economy according to economists?

Countries do not actually have to be market economies to be awarded this status. What they must do is to demonstrate that significant progress has been made and that the country's economy is following the path towards inevitably becoming a market economy.

In 2001, the official Department of Commerce view was that Kazakhstan was becoming a market economy:

Kazakhstan is continuing its transition to a market economy. Key reforms underway include completing Kazakhstan's privatization program, nurturing the nascent securities market, consolidating gains in pension reform and the banking sector, improving the investment climate and continuing to modify the

\footnotetext{
European Union. 2000. “Council Regulation (EC) No. 2238/2000 9 October 2000,” Official Journal of the European Communities. 11 October. L257: 2-3

${ }^{5}$ Vedrine,H., President of the EU Council. 2000. Council Regulation (EC) No 2238/2000 of 9 October 2000 amending Regulation (EC) No 384/96 on protection against dumped imports from countries not members of the European Community.

${ }^{6}$ Source is Tatiana Romon, of the European Union's Delegation of the European Commission in Kazakhstan.
} 
trade regime as part of Kazakhstan's efforts to join the World Trade Organization (WTO). ${ }^{7}$

That is not to say that the EU and the USA lack any set of criteria. There are conditions that must be met before a country is called a market economy by either.

\begin{tabular}{|l|l|l|}
\hline Market-determined prices & European Union Criteria & $\begin{array}{l}\text { U.S. Department of } \\
\text { Commerce Criteria }\end{array}$ \\
\hline Control of resources & $\begin{array}{l}\text { State interference must be } \\
\text { minor. }\end{array}$ & $\begin{array}{l}\text { Wage rates are established by } \\
\text { the labor market. }\end{array}$ \\
\hline $\begin{array}{l}\text { Disappearance of undue state } \\
\text { control over resources and } \\
\text { production decisions Law is } \\
\text { transparent and non-discri- } \\
\text { minatory. }\end{array}$ & $\begin{array}{l}\text { State-ownership of resources is } \\
\text { minimal. }\end{array}$ \\
\hline Accounting standards & $\begin{array}{l}\text { International standards are } \\
\text { followed. } \\
\text { There are no holdovers from } \\
\text { planned economy payment of } \\
\text { debts, such as write-offs, barter, } \\
\text { or payment through compen- } \\
\text { sation of debts. }\end{array}$ & \\
\hline Property Rights & $\begin{array}{l}\text { Law is transparent and effect- } \\
\text { tive. } \\
\text { Insolvent firms are forced into } \\
\text { bankruptcy. }\end{array}$ & \\
\hline Exchange Rates & Exchange rates are not fixed. & Currency is convertible. \\
\hline Foreign Investment & $\begin{array}{l}\text { There is potential for foreign } \\
\text { investment. }\end{array}$ \\
\hline
\end{tabular}

Criteria set by the EU seem more restrictive than those of the USA. The former emphasizes liberalization of all prices, not just wages. Much is made of accounting standards, which do not appear to be emphasized by the USA. The EU underscored property rights, whereas the USA put emphasis on opportunities for FDI. Both sets place stress upon removing currency controls and both emphasize private use of resources.

Many transition economies also wish to join the European Union. For these countries, there are additional requirements. ${ }^{8}$ Democratic institutions, including the rule of law, respect for human rights, and protection of minorities, must be supported. The country must be willing to support the political, economic, and monetary aims of the union. The economy should be able to cope with added competition pressures that EU membership will bring. For those European

\footnotetext{
${ }^{7}$ Unites States Trade Representative. 2001. Foreign Trade Barriers, Kazakhstan. 30 March.

${ }^{8}$ European Union. Enlargement.
} 
countries such as Poland, Slovenia, Croatia, Latvia, etc. that hope for full integration into Europe's markets, political and economic requirements are stricter.

While Kazakhstan closely follows its big brother of Russia, Russia has satisfied the EU criteria, while Kazakhstan has not.

Economists have created conditions for accessing countries' progress towards becoming a market economy and for comparing the progress of transition economies. The well-known Hungarian, author of Hiways and Byways, Kornai (2000) is one. ${ }^{9}$ Svejnar (2002) is another. ${ }^{10}$ Also considered are Melo et al (1996), ${ }^{11}$ Lavigne (1999), ${ }^{12}$ and Frydman \& Rapaczynski (1994). ${ }^{13}$

Kornai's conditions compare the differences between socialism and capitalism. They include factors such as state control of property and resources, as did the American and European criteria sets. However, Kornai also looks at political party attitudes and whether producers or consumers dominate the economic system.

\section{Table: Kornai’s Classification}

SOCIALISM

\begin{tabular}{|c|c|c|}
\hline 1: Political Control & Central Party & Pro-private property party \\
\hline 2: Economic Control & $\begin{array}{l}\text { State dominates the econ- } \\
\text { omy. }\end{array}$ & $\begin{array}{l}\text { Private property interests } \\
\text { dominate the economy. }\end{array}$ \\
\hline $\begin{array}{l}\text { 3: Economic Coordina- } \\
\text { tion }\end{array}$ & $\begin{array}{l}\text { Bureaucratic organization } \\
\text { and coordination }\end{array}$ & $\begin{array}{l}\text { Allocation and production } \\
\text { decisions are market-based. }\end{array}$ \\
\hline 4: Resource Efficiencies & Soft budget constraints & Hard budget constraints \\
\hline 5: Market Efficiencies & $\begin{array}{l}\text { Sellers market; goods' short- } \\
\text { ages; and labor short-age }\end{array}$ & $\begin{array}{l}\text { Buyers' Market; no shortages, } \\
\text { and unemployment }\end{array}$ \\
\hline
\end{tabular}

Kornai emphasized points 1-3: private property is protected and dominates the economy and private parties control resources. When this occurs, according to Kornai, the country is on the whole a market economy as transition is mostly complete.

\footnotetext{
${ }^{9}$ Kornai, J. 2000a. What the Change of System from Socialism to Capitalism Does and Does Not Mean," The Journal of Economic Perspectives. 14(I): 27-42.

${ }^{10}$ Svejnar, J. 2002. "Transition Economies: Perfection and Challenges," Journal of Economic Perspectives 16(1) Winter: 3-28.

${ }^{11}$ De Melo, M.; Denizer, C.; \& Gelb, A. 1996. From Plan to Market, Patterns of Transition. The World Bank Policy Research Department, Transition Economics Division. January. Working Paper No. 1564.

${ }^{12}$ Lavigne, M. 1999. The Economics of Transition From Socialist Economy to Market Economy. (London: Macmillan Press): 276.

${ }^{13}$ Frydman, R. \& Rapaczynski, A. 1994. Privatization in Eastern Europe: Is the State Withering Away? (Oxford: Oxford University Press)
} 
Neoclassical economists, who advised transition economy leaders in the early 1990's, believed that market activity would spontaneously occur, once controls were lifted. Kornai also felt that by removing state controls, the barriers to capitalism were removed. So removal of politically created, economic barriers is a major component of transition.

Kornai does not argue that democracy is a necessary condition for capitalism, but that capitalism is a necessary condition for democracy.

Using Kornai's classification for what makes a "capitalist" economy, we see that efficiency is not a necessary condition. On the other hand, private property rights and pricecoordination are. This is an institutionalist approach. In another piece by Kornai, he writes that, "the transition from socialism to capitalism has to be an organic development. It cannot be done otherwise. It is a curious amalgam of revolution and evolution." ${ }^{14}$ The revolution began in 1991 when the Soviet Union dissolved. The evolution has been occurring since then.

Let us examine how well Kazakhstan has satisfied Kornai's criteria.

- Does the dominant political party protect property rights? Kazakhstan has privatized all property except for land. There is currently a problematic land reform plan that is scheduled to begin in 2007. There are bankruptcy and property laws. However, problems in clarifying the legal code and high corruption cannot ensure the sanctity of property rights. Kazakhstan has mostly, but not fully satisfied Kornai's first criterion.

- Is the state's role in resource management and production decisions minimal? The largest sector in the Kazakhstani economy is oil and gas. The government controls oil and gas resources, and investment in this sector has led to the development of new large stateenterprises.

The share of state-owned industrial production as a percentage of the total fell from 74.6 to 2.5 percent $^{15}$ between 1992 and 2000. However, 33.5 percent of farms were private, and 18.9 percent of rural land was privately owned in $2000 .{ }^{16}$ (This is soon to be changed in 2007.)

Kazakhstan plans to liberalize control of land resources, but there are no plans for liberalizing oil and gas resources.

\footnotetext{
${ }^{14}$ Kornai, J. 2000b. "Ten Years After the Road to a Free Economy: The Author's Self Evaluation," World Bank Annual Bank Conference on Development Economics. April 18-20 2000.

${ }^{15}$ Statistical Agency of the Republic of Kazakhstan. 2001. Statisticheski Yezhagodnik Kazakhstan. (Almaty: Statistical Agency of Kazakhstan): 248.

${ }^{16}$ Ibid: 255.
} 
- Who, or what, coordinates economic decisions? Decisions on what to produce and how to produce are mostly independent of government control. One key exception is restrictive labor laws (and no WTO “national treatment"), making it difficult to import specialized workers. Another is the control of oil and gas resources.

- Hard budget constraints appear to have replaced soft, thus satisfying the third criterion.

- The fourth issue is are resources allocated efficiently? Labor and capital markets are independent of government intervention.. There appears to be little state-directed investment, and the minimum wage is so low as to appear non-binding upon private employers. ${ }^{17}$ Land allocation will be changing in 2007.

- Is the economy efficient? Efficiency is usually indicated by normalization of prices. This is not the case in Kazakhstan, even within the same area. Inadequate infrastructure, especially in the rural sector, creates problems for rural producers.

There is low official unemployment (10-11 percent), but high underemployment. Government salaries and pensions are very low. The former results in talented people leaving the public sector and encourages state capture.

A strong indicator of economic efficiency, when governance issues are factored in, is the Index of Economic Freedom, which ranks countries from 1 (best) to 5 (worst). Kazakhstan began in 1998 with a rating of 4.28. ${ }^{18}$ It has improved its ranking to 3.70 in 2002 and 2004 (economic freedom worsened in 2003). Kazakhstan was downgraded for its barriers to capital flows. The fiscal burden of the government, price and wage liberalization, and low government intervention were the country's best attributes.

Kornai's criteria require that a country has moved from the planned system to the market system, minimally with respect to points 1 to 3 in the table above. Point 3 is satisfied, but Kazakhstan has not yet moved from the planned to the market system in points 1 and 2 . Kazakhstan is not yet a market economy.

\footnotetext{
${ }^{17}$ Minimum wager-earners are usually civil servants. For example, $\$ 50$ is about the lowest wage for an unskilled worker who is privately hired. Public employees are often paid the legal minimum wage, which is less (\$36 in March 2004).

${ }^{18}$ Miles, M., Feulner, Jr., E. \& O’Grady, M. 2004. Index of Economic Freedom. (Washington D.C.: Heritage Foundation): 247. For comparison, this is the same rating that Bangladesh and Yemen received.
} 
Svejnar looks at three classes of variables in comparing the success of transition economies: macroeconomic stabilization; microeconomic restructuring; and social indicators. ${ }^{19}$ Judging success requires a somewhat deeper mode of analysis than deciding if an economy is or is not a market one. The analysis has changed from a bimodal one to a qualitative one.

The argument is that market economies are Pareto superior to planned economies, because they can improve quality of life the most. Since all transition economies are evolving towards, or have already become, market systems, those that are more successful should be more market-oriented. Anecdotal evidence supports this. Life in reformed Poland and Slovenia is significantly better than life in Russia which is less market oriented than they, which is still better than life in reform-resistant countries like Turkmenistan.

Svejnar judges that transition is complete when government monopoly ceases and economic growth is evident. "I would define the end of transition as a state when these economies replace central planning by a functioning market system and when they generate rapid and sustained rates of economic growth that enable them to interact with the more advanced market economies without major forms of protection." ${ }^{20}$ In this 2002 work, Svejnar did not categorize FSU countries as nearly market economies, but did comment favorably upon Estonia, Poland, the Czech Republic, Hungary, Slovenia, and the Slovak Republic.

Can Kazakhstan satisfy Svejnar's standards?

- Has the macroeconomy stabilized? Kazakhstan currently has high growth in GDP, which is currently about 10 percent per annum. Growth rates increased between 1998 and 2000, from 5.1 to 14.9 to 18.8 percent. $^{21}$ However, growth in the Kazakhstani economy is more of a function of oil and gas prices, than it is of increased output. Inflation in the 2000's is in the teens. The government has done much, spending and investing little and saving much, to pay debts and maintain fiscal surpluses. The economy in 2004 appears to be continuing its trend of healthy growth.

19 Svejnar's criteria are almost exactly those suggested by the IMF (2000). The IMF's criteria include (i) liberalization; (ii) stabilization; (iii) restructuring of firms; and (iv) legal and institutional reform.

${ }^{20}$ Svejnar, J. 2002. “Transition Economies: Perfection and Challenges,” Journal of Economic Perspectives 16(1) ${ }^{21}$ Ibid: 10 . 
- Have firms been restructured? Firms are mostly privately owned and are undergoing restructuring. Officially published statistics state that in 2001, 16.1 percent of all firms were state-owned. ${ }^{22}$ Privatization statistics are presented in Table 4.

State-owned firms are still most common for large-size firms (59\%). Eighty-one percent of small-size firms are privately owned. ${ }^{23}$

Foreign investment is allowed. Foreigners must control less than 50 percent of a firm, or a resident may create a local, Kazakhstani corporation. FDI in Kazakhstan is primarily in the oil and gas sector. From 1993 to 1999 Kazakhstan received almost 10 billion USD in direct investment from foreign investors. Total FDI per capita for 2000 was 2.75 billion USD of which 71 percent was in the "Mining Sector" (oil and gas). ${ }^{24}$

Rural privatization through the Land Code was proposed in 2002, and approved by the Parliament in March 2003. This plan called for the privatization of 90 million hectares of land and for sales to be limited to citizens of Kazakhstan. ${ }^{25}$ The program begins in 2007, when hectares of land will be sold at fixed prices: $\$ 100$ to $\$ 400$ per hectare of arable land and $\$ 400$ to $\$ 1,600$ per hectare of the best arable land.

How are social indicators in Kazakhstan? Below are statistics from 1995 and 2001. Deaths are down moderately. Infant mortality and homicide statistics have been greatly improved. Both marriage and divorce rates are creased. The birth rate is down substantially. The third Svejnar criterion is the existence of favorable social indicators, as indicators of institutional development. From these indicators, there is room for progress, but life appears to be improving.

${ }^{22}$ Statistical Agency of the Republic of Kazakhstan (2002)

${ }^{23} \mathrm{Ibid}$.

${ }^{24} \underline{\text { Ibid. }}$.

${ }_{25}$ Konstantinov, A. 2003. "Parliament pushing for private ownership of Kazakh agricultural land," The Kazakhstan Monitor 10(27), 14 March: 2. 
Table: Social Indicators

\begin{tabular}{|l|l|l|l|l|l|l|l|}
\hline Year & Births & Deaths & Infant & Homicide & Suicide & Marriage & Divorce \\
\cline { 2 - 8 } & 11000 & 11000 & Mortality & $/ 100000$ & $/ 100000$ & $/ 1000$ & 1000 \\
\hline 1995 & 17,5 & 10,2 & 25,4 & 20,3 & 29,9 & 7,3 & 2,4 \\
\hline 2001 & 14,6 & 10,0 & 19,6 & 15,6 & 29,7 & 6,3 & 2,0 \\
\hline $\begin{array}{l}95-01 \\
\text { Change }\end{array}$ & $\downarrow 16,6 \%$ & $\downarrow 2,3 \%$ & $\downarrow 22,8 \%$ & $\downarrow 23,2 \%$ & $\downarrow 0,7 \%$ & $\downarrow 13,7 \%$ & $\downarrow 16,7 \%$ \\
\hline
\end{tabular}

Source: Statistical Agency of the Republic of Kazakhstan $(1999,2002)$

The World Bank reported that longevity in Kazakhstan was the lowest among all transition countries. ${ }^{26}$ The statistics from the Statistical Agency of Kazakhstan generally point in the direction of improved living standards, yet longevity remains low. The most recent statistic was 71.1 years for women and 60.2 years (less than the age of retirement) for men. ${ }^{27}$ It is not known how much economic conditions (and the stress of change, unemployment, and poverty) and how much Kazakhstan's environmental problems ${ }^{28}$ are at fault. Otherwise, the only negative indicators were a rural fertility rate, that fell substantially, and a slightly lower number of per capita marriages.

Using Svejnar's criteria, of macroeconomic stabilization, microeconomic restructuring, and social, health indicators, would suggest that Kazakhstan is, or is nearly, a market economy. The economy is growing and macroeconomic variables are about where expected. Inflation rates are high, but not excessively. Microeconomic restructuring results are mixed. Privatization has been limited thus far. There is a large discrepancy in incomes following independence. Unemployment and underemployment remain high. Kazakhstani firms in general are not attracting much foreign investment; FDI is concentrated in the oil and gas sector. Indicators of health have nearly all improved in recent years. Longevity statistics still hold Kazakhstan down Kazakhstan does not satisfy Svejnar's criteria perfectly, but it seems on the threshold of doing so.

\footnotetext{
${ }^{26}$ World Bank. 2003. Europe and Central Asia: Regional data from the WDI database.

27 Statistical Agency of Kazakhstan. 2001. Statisticheskii Yezhegodnik. (Almaty: Statistical Agency of the RK).

${ }^{28}$ Kazakhstan has non-economic conditions that will decrease lifespan: urban pollution, Aral Sea environmental degradation, and radiation from former Soviet nuclear testing.
} 
Another well-known paper on the process of reform in transition countries is de Melo et al (1996). ${ }^{29}$ This paper contrasts the economic differences between the planned, Soviet system and the transition stage. This is followed by the author's expected results after the transitional period has been completed and a nascent market economy is firmly in place.

Table: de Melo et al's Changes from Planned to Transitional Economies Planned System Transitional Period

\begin{tabular}{|lll|}
\hline Macroeconomic balances & $\begin{array}{l}\text { Balances are achieved } \\
\text { through direct government } \\
\text { supervision. }\end{array}$ & Destabilized. \\
\hline $\begin{array}{l}\text { Economic, political, and } \\
\text { social decision-making }\end{array}$ & $\begin{array}{l}\text { These are coordinated } \\
\text { through the Party. }\end{array}$ & $\begin{array}{l}\text { Coordinating mechanisms are } \\
\text { disrupted. }\end{array}$ \\
\hline Private ownership & Minimal. & Growth of private sector. \\
\hline Relative prices & Distorted. & $\begin{array}{l}\text { Structural reallocation of } \\
\text { resources. }\end{array}$ \\
\hline
\end{tabular}

${ }^{29}$ De Melo, M.; Denizer, C.; \& Gelb, A. 1996. From Plan to Market, Patterns of Transition. The World Bank Policy Research Department, Transition Economics Division. January. Working Paper No. 1564. 
Let us pursue this evolution, to results that are expected when transition is completed, or mostly completed.

Table: Results of Changes when Transition is Complete Transition is complete.

\begin{tabular}{|l|l|}
\hline Macroeconomic balances & $\begin{array}{l}\text { Changes in GDP are not } \\
\text { erratic; inflation and } \\
\text { unemployment are within the } \\
\text { bounds of a similar, non- } \\
\text { transition economy. }\end{array}$ \\
\hline $\begin{array}{l}\text { Economic, political, and } \\
\text { social decision-making }\end{array}$ & $\begin{array}{l}\text { Private interests, rather than } \\
\text { politicians, direct changes in } \\
\text { the society. } \\
\text { Citizens have an under- } \\
\text { standing of how markets } \\
\text { work, so that rational deci- } \\
\text { sions can be made. }\end{array}$ \\
\hline Private ownership & $\begin{array}{l}\text { Registration of property is } \\
\text { clear and rights are } \\
\text { effectively, not nominally, } \\
\text { protected by court of law. }\end{array}$ \\
\hline Relative prices & $\begin{array}{l}\text { Market mechanisms are } \\
\text { mostly able to prevent } \\
\text { shortages and surpluses and } \\
\text { information is available, so } \\
\text { that relative prices are } \\
\text { correct. }\end{array}$ \\
\hline
\end{tabular}

We use de Melo et al's conditions during reform to predict expected results when a country has evolved from a non-market to a market economy. Instabilities are replaced by the relative stability of a market economy. Ignorance of market operations is replaced with sufficient understanding to make seemingly rational decisions. Not only does private property exist, but also these rights are protected by a court and registration system that is efficient and fair.

Whether an economy is, or is not, a market economy does not depend on proclamations that private enterprise will happen or by privatization or by regaining lost output. Institutional development is necessary or a country will remain a transition economy and never fully mature. Changes in macroeconomic indicators will be erratic; decision making is impaired; property rights are not truly secure; and prices remain distorted. It is evident in Kazakhstan today that although it may be a "market economy" according to the USA, that it has not completed its transition, if one follows these criteria. Something more is needed than simply stabilization, 
privatization and the recovery of growth rates. It requires basic economic literacy and savvy and decision making that is nearly free of political considerations.

Lavigne (1999) goes farther by writing that a when we are no longer constantly reminded that an economy was once a planned economy, then transition is complete. Using these criteria, few FSU countries would pass this test and countries such as Slovenia would easily pass them. Lavigne also uses EU accession eligibility for European transition economies as a robust test for completion of a country's transition.

Frydman \& Rapaczynski $(1994)^{30}$ described "transition" as a period of state withdrawal from its central position. Following this line of thought, we can conclude that transition is complete when the government no longer can sets prices and controls resources.

In Kazakhstan, government mostly does not set prices, although its national wealth of oil and gas reserves are controlled by the government. This, however, is not dissimilar to many socialist, developed countries. Investment in oil and gas has even encouraged many large, new state enterprises to be created. It is not clear, if the government, ${ }^{31}$ which is largely controlled by a strong president, has withdrawn from economic decision making.

However, Frydman \& Rapaczynski also point out that market decisions are frequently made through institutions, such as corporations, rather than individuals making independent decisions. The processes of obtaining information, dissemination, analysis, and decision making are created by cooperating individuals. Managers control the flow of information while government regulators maintain the interests of the general society. Managers must understand market signals, know where to find information, and how to respond to it. If this is absent, then command-and-control management could be more efficient than private management. In the early 1990s, the belief was that decentralization would release productive energies. This is not evident in all transition economies. One explanation for this is the institutional type explanation, such as Frydman \& Rapaczynski’s.

It is clear in Kazakhstan that dissemination of information is a mess. This is particularly the case when it comes to governance issues. The rules are quite strict, but ways to adhere to the rules are not commonly known, which creates opportunities for corruption. Laws are not well

\footnotetext{
${ }^{30}$ Frydman, R. \& Rapaczynski, A. 1994. Privatization in Eastern Europe: Is the State Withering Away? Central European University Privatization Project 1994 (Oxford: Oxford University Press)

31 The government consists of a strong president who dominates the courts and Parliament. Government is still centralized with local government leaders answering to those in the capital of Astana.
} 
understood and courts implement them in a free manner. Statistical data for the republic is quite good. Little is known about consumers.

As has been suggested here, institutions are needed to support a fair and efficient economic system. These institutions are partly cultural. Fair market practices may be understood, but completely ignored, because the culture does not yet support them. In other cases, market economic behavior is learned, and people are learning this more slowly than economists imagined.

Linz (2000) asked, “are Russians really ready for capitalism?” She found deviations in Russian students' attitudes from American ones, that she felt would undermine market development. So long as beliefs needed for market institutions are weak, the institutions cannot exist. So long as necessary economic institutions are absent, transition cannot be complete.

Without survey data, it is difficult to answer if Kazakhstanis are ready for capitalism. It seems that they are certainly ready for the wealth that foreign investment and exploitation of natural resources have delivered, not to mention rent-seeking activities in the early years of independence. However, many people look fondly upon the days of Soviet order and egalitarianism. What is also evident is that Kazakhstanis are not ready in the sense that basic understanding of such issues as supply-and-demand, service-mentality, and the sanctity of contracts are lacking.

\section{Conclusion}

The initial questions were: how did the USA and the EU arrive at different decisions concerning Kazakhstan's market status and do analyses by economists differ from the findings of the EU and USA?

The answers to these questions lie partly in the nature of the criteria set and partly in the fact that political agencies, as opposed to academic economists, are making these decisions. Independent, academic economists are less likely to be swayed by political considerations, such as a gratitude for Kazakhstan's giving up nuclear weapons or the desire for Kazakhstan's oil and gas reserves, or for its pro-western stance in international politics. Secondly, we see that both criteria sets are limited, the USA's more so than the EU's. Their criteria are binomial: yes or no. Those of economists are more qualitative. Svejnar includes welfare factors; Lavigne includes 
perceptions. Here we also emphasize knowledge of basic business and economics by the citizenry, the rapid evolution of which was taken for granted in the early 1990's.

Having discussed several academic works on the subject, we see that Kazakhstan is not yet a market economy. This conclusion is based upon the fact that it does not fully satisfy any of the criteria sets that can be created from the work of theoretical economists. Kazakhstan does, however, satisfy many of these criteria. Hence, it is more likely that academic economists would be more in agreement with the conclusions of the EU than with the U.S. Department of Commerce. 


\section{References:}

De Melo, M.; Denizer, C.; \& Gelb, A. 1996. From Plan to Market, Patterns of Transition. The World Bank Policy Research Department, Transition Economics Division. January. Working Paper No. 1564

Djankov, S. \& Murrell, P. 2002. "Enterprise Restructuring in Transition" Journal of Economic Literature XL, September: 739-792

Dusanova, D. 2001. "Evolution of capitalism in the post-communist societies," Central Asian Journal of Management, Economics, and Social Research, (2): 127-133

Eicher, S. 2003. "When does a Transition Economy Become a Market Economy? The Example of Kazakhstan," Journal of Central Asian Studies. November.

European Commission. 1997. Central and Eastern Eurobarometer (CEEB 8) $<$ http://europa.eu.int> (19 March 2003)

2000. “Council Regulation (EC) No. 2238/20009 October 2000," Official Journal of the European Communities. 11 October. L257

—_— 2002a. Candidate Countries Eurobarometer. <http://europa.eu.int> (19 March 2003)

—— 2002a. Applicant Countries Eurobarometer. <http://europa.eu.int> (19 March 2003)

-—— 2002c. Ninth E.U.-Russia Summit, Moscow, 29 May 2002. < http://europa.eu.int> (22 February 2003)

- — 2002d. Bilateral Trade Relations, Kazakhstan, August. <http://europa.eu.int/> (22 February 2003)

———Enlargement. <http://europa.eu.int> (12 March 2003)

Fischer, S., Sahay, R. \& Vegh, C. 1996. "Stabilization and Growth in Transition Economies," Journal of Economic Perspectives. 10(2): 45-66

Frydman, R. \& Rapaczynski, A. 1994. Privatization in Eastern Europe: Is the State Withering Away? Central European University Privatization Project 1994 (Oxford: Oxford University Press)

International Monetary Fund. 2000. Transition Economies: An IMF Perspective on Progress and Prospects. No. 00/08. 3 November. <www.imf.org> (15 April 2003)

Koliandre, Alexander. 2002. "US calls Russia a market economy," $B B C$ News. 7 June. $<$ http://news.bbc.co.uk> (22 February 2003) 
Konstantinov, A. 2003. "Parliament pushing for private ownership of Kazakh agricultural land," The Kazakhstan Monitor 10(27), 14 March.

Kornai, J. 1995. Highways and Byways. (Cambridge: MIT Press)

- - 2000a. What the Change of System from Socialism to Capitalism Does and Does Not Mean," The Journal of Economic Perspectives. 14(I): 27-42

2000b. "Ten Years After the Road to a Free Economy: The Author's Self

Evaluation," World Bank Annual Bank Conference on Development Economics. April 18-20 2000

Kulekeyev, Zh. (ed.) 1999. Statisticheskii Yezhegodnik. (Almaty: Agency on Statistics of the Republic of Kazakhstan).

Larson, A. 2002. Finishing The Transformation. Remarks by the U.S. Under-Secretary of State for Economic, Business, and Agricultural Affairs. at the Kazakhstan Institute of Management, Economics and Strategic Research (Almaty, Kazakhstan)

Lavigne, M. 1999. The Economics of Transition From Socialist Economy to Market Economy. (London: Macmillan Press)

Linz, S. 2000. Are Russians Really Ready for Capitalism? William Davidson Institute Working Paper No. 268

Miles, M., Feulner, Jr., E. \& O'Grady, M. 2004. Index of Economic Freedom. (Washington D.C.: Heritage Foundation).

Muzaparova, L. 2002. "Problemi ustoichivovo razvitiye v Kazahstane," Kazakhstanski Institut Stratigicheskih Isledovanii Pri Prezidente Kazakhstan. < http://www.kisi.kz> (11 January 2003).

Nichols, P. 2001. "Privatization techniques for Central Asia," Central Asian Journal of Management, Economics, and Social Research, (2): 45-56

Nos, I. 2003. "Resolving Set Tasks," Kazakhstan Pravda <www.kazpravda.kz/e_e.html> (10 April 2003)

Roland, G. 2002. "The Political Economy of Transition," Journal of Economic Perspectives, 16(1), Winter: $29-50$

Schleifer, A. 1998. "State versus Private Ownership," Journal of Economic Perspectives, 12(4), Fall: $133-150$.

Serna, L. A. President of the EU Council. 1995. COUNCIL REGULATION (EC) No 384/96 of 22 December 1995 on protection against dumped imports from countries not members of the European Community. 22 December. 
Smailov, A. (ed.) 2002. Statistical Agency of the Republic of Kazakhstan. 2002. Statisticheski Yezhagodnik (Almaty: Statistical Agency of Kazakhstan).

Statistical Agency of the Republic of Kazakhstan. 2001. Statisticheski Yezhagodnik Kazakhstana. (Almaty: Statistical Agency of Kazakhstan).

Svejnar, J. 2002. "Transition Economies: Perfection and Challenges," Journal of Economic Perspectives 16(1) Winter: 3-28.

Taronishev, B. 2003. "Privatization to the accompaniment of the cannonade," The Kazakhstan Monitor 13(30) 4 April: 2.

United States Department of Commerce. 2002a. The Status of the Russian Federation as a NonMarket Economy Country under the Antidumping and countervailing Duty Laws.

$<$ http://www.usrbc.org $>$ (22 February 2003)

- - 2002b. FACT SHEET, Market Economy Analysis of Kazakhstan. Office of Public Affairs. <http://www.ita.doc.gov> (22 February 2003)

—__ 2002c. "Kazakhstan gains market economy status" BISNIS Bulletin. April. $<$ http://www.bisnis.doc.gov> (22 February 2003)

United States Department of State. 2001a. Background Note: Kazakhstan. Bureau of European and Eurasian Affairs. <http://www.state.gov> (10 April 2003)

2001b. Statement on New Kazakhstan-American Relationship. International Information Programs. 21 December. $<$ http://usinfo.state.gov> (10 April 2003)

Unites States Trade Representative. 2001. Foreign Trade Barriers, Kazakhstan. 30 March. $<$ http://www.ustr.gov/html/2001_kazakst.pdf $>$ (22 February 2003)

Vedrine, H. 2000. President of the EU Council. 2000. Council Regulation (EC) No 2238/2000 of 9 October 2000 amending Regulation (EC) No 384/96 on protection against dumped imports from countries not members of the European Community.

Vigilante, A. 1998. "The State of Transition \& Transformation of the State," National Human Development Report. UNDP (New York: United Nations)

Whitesides, J. 2001. "US Congress to consider Russia trade test exemption," Johnson's List. \#5524. 3 November. <www.cdi.org/russia/johnson/5524-1.cfm> (10 April 2003)

Whitehouse. 2001. Jackson-Vanik and the Russia Fact Sheet. News Release from President George Bush. <www.whitehouse.gov> (10 April 2003) 
World Bank. 2003. Europe and Central Asia: Regional data from the WDI database. $<$ www.worldbank.org > (21 April 2003).

World Trade Organization. ACC: How to accede. <www.wto.org> (20 March 2003). 


\section{DAVIDSON INSTITUTE WORKING PAPER SERIES - Most Recent Papers}

The entire Working Paper Series may be downloaded free of charge at: www.wdi.bus.umich.edu

CURRENT AS OF 4/8/04

\begin{tabular}{|c|c|c|}
\hline Publication & Authors & Date \\
\hline No. 673: Is Kazakhstan a Market Economy Yet? Getting warmer.... & Sharon Eicher & Apr. 2004 \\
\hline $\begin{array}{l}\text { No. 672: Financial Institutions and The Wealth of Nations: Tales of } \\
\text { Development }\end{array}$ & Jian Tong and Chenggang Xu & Apr. 2004 \\
\hline $\begin{array}{l}\text { No. 671: Interest Rate Pass-Through in EU Acceding Countries: The } \\
\text { Case of the Czech Republic, Hungary and Poland }\end{array}$ & $\begin{array}{l}\text { Jesús Crespo Cuaresma, Balázs } \\
\text { Égert, and Thomas Reininger }\end{array}$ & Mar. 2004 \\
\hline $\begin{array}{l}\text { No. 670: A minimum of rivalry: evidence from transition economies on } \\
\text { the importance of competition for innovation and growth }\end{array}$ & $\begin{array}{l}\text { Wendy Carlin, Mark Schaffer and } \\
\text { Paul Seabright }\end{array}$ & Mar. 2004 \\
\hline No. 669: Dual Track Liberalization: With and Without Losers & $\begin{array}{l}\text { Jiahua Che and Giovanni } \\
\text { Facchini }\end{array}$ & Mar. 2004 \\
\hline $\begin{array}{l}\text { No. 668: Enterprise Restructuring and Firm Performance: } \\
\text { A Comparison of Rural and Urban Enterprises in Jiangsu Province }\end{array}$ & $\begin{array}{l}\text { Xiao-yuan Dong, Louis } \\
\text { Putterman and Bulent Unel }\end{array}$ & Mar. 2004 \\
\hline $\begin{array}{l}\text { No. 667: A Tale of Two Provinces: The Institutional Environment and } \\
\text { Foreign Ownership in China }\end{array}$ & Yasheng Huang and Wenhua Di & Mar. 2004 \\
\hline $\begin{array}{l}\text { No. 666: Ownership Characteristics and Access to Finance: } \\
\text { Evidence from a Survey of Large Privatised Companies in Hungary } \\
\text { and Poland }\end{array}$ & $\begin{array}{l}\text { Natalia Isachenkova and Tomasz } \\
\text { Mickiewicz }\end{array}$ & Mar. 2004 \\
\hline $\begin{array}{l}\text { No. 665: Testing Creditor Moral Hazard in Sovereign Bond Markets: } \\
\text { A Unified Theoretical Approach and Empirical Evidence }\end{array}$ & $\begin{array}{l}\text { Ayșe Y. Evrensel and Ali M. } \\
\text { Kutan }\end{array}$ & Mar. 2004 \\
\hline $\begin{array}{l}\text { No. 664: Assessing Equilibrium Exchange Rates in CEE Acceding } \\
\text { Countries: Can We Have DEER with BEER without FEER? }\end{array}$ & Balázs Égert & Feb. 2004 \\
\hline $\begin{array}{l}\text { No. 663: Modelling stock returns in the G-7 and in selected CEE } \\
\text { economies: A non-linear GARCH approach }\end{array}$ & Balázs Égert and Yosra Koubaa & Feb. 2004 \\
\hline $\begin{array}{l}\text { No. 662: Institutional Change and Product Composition: Does the Initial } \\
\text { Quality of Institutions Matter? }\end{array}$ & $\begin{array}{l}\text { Johannes Moenius and Daniel } \\
\text { Berkowitz }\end{array}$ & Feb. 2004 \\
\hline No. 661: Dual track liberalization: With and without losers & $\begin{array}{l}\text { Jiahua Che and Giovanni } \\
\text { Facchini }\end{array}$ & Feb. 2004 \\
\hline $\begin{array}{l}\text { No. 660: Who Is in Favor of Enlargement? Determinants of Support for } \\
\text { EU Membership in the Candidate Countries' Referenda }\end{array}$ & Orla Doyle and Jan Fidrmuc & Feb. 2004 \\
\hline $\begin{array}{l}\text { No. 659: Creditor Moral Hazard in Equity Markets: } \\
\text { A Theoretical Framework and Evidence from Indonesia and Korea }\end{array}$ & $\begin{array}{l}\text { Ayşe Y. Evrensel and Ali M. } \\
\text { Kutan }\end{array}$ & Feb. 2004 \\
\hline No. 658: Worsening of the Asian Financial Crisis: Who is to Blame? & $\begin{array}{l}\text { Brasukra G. Sudjana and Ali M. } \\
\text { Kutan }\end{array}$ & Feb. 2004 \\
\hline $\begin{array}{l}\text { No. 657: European Integration, Productivity Growth and Real } \\
\text { Convergence }\end{array}$ & Taner M. Yigit and Ali M. Kutan & Feb. 2004 \\
\hline $\begin{array}{l}\text { No. 656: The Impact of News, Oil Prices, and Global Market } \\
\text { Developments on Russian Financial Markets }\end{array}$ & Bernd Hayo and Ali M. Kutan & Feb. 2004 \\
\hline No. 655: Politics and Economic Reform in Malaysia & Bryan K. Ritchie & Feb. 2004 \\
\hline No. 654: The Evolution of Income Inequality in Rural China & $\begin{array}{l}\text { Dwayne Benjamin, Loren Brandt } \\
\text { and John Giles }\end{array}$ & Feb. 2004 \\
\hline $\begin{array}{l}\text { No. 653: The Sources of Real Exchange Fluctuations in } \\
\text { Developing Countries : an Econometric Investigation }\end{array}$ & Imed Drine and Christophe Rault & Feb. 2004 \\
\hline $\begin{array}{l}\text { No. 652: Ownership, Control and Corporate Performance After } \\
\text { Large-Scale Privatization }\end{array}$ & $\begin{array}{l}\text { Jan Hanousek, Evzen Kocenda } \\
\text { and Jan Svejnar }\end{array}$ & Feb. 2004 \\
\hline $\begin{array}{l}\text { No. 651: Czech Social Reform/Non-reform: Routes, Actors and } \\
\text { Problems }\end{array}$ & Jiri Vecernik & Feb. 2004 \\
\hline $\begin{array}{l}\text { No. 650: Financial Integration, Exchange Rate Regimes in CEECs, } \\
\text { and Joining the EMU: Just Do It... }\end{array}$ & Maurel Mathilde & Feb. 2004 \\
\hline $\begin{array}{l}\text { No. 649: Corporate Investments, Liquidity and Bank Financing: } \\
\text { Empirical Evidence from an Emerging Market }\end{array}$ & Arun Khanna & Feb. 2004 \\
\hline $\begin{array}{l}\text { No. 648: Financial Constraints in Investment - Foreign Versus } \\
\text { Domestic Firms. Panel Data Results From Estonia, 1995-1999. }\end{array}$ & $\begin{array}{l}\text { Tomasz Mickiewicz, Kate Bishop } \\
\text { and Urmas Varblane }\end{array}$ & Feb. 2004 \\
\hline $\begin{array}{l}\text { No. 647: Legal Minimum Wages and the Wages of Formal and Inform } \\
\text { Sector Workers in Costa Rica }\end{array}$ & $\begin{array}{l}\text { T. H. Gindling and Katherine } \\
\text { Terrell } \\
\end{array}$ & Feb. 2004 \\
\hline
\end{tabular}

